\title{
PENGEMBANGAN APLIKASI KEUANGAN DI SPBU SERA KM 25 SIDOARJO
}

\author{
Galang Audi Pramasha ${ }^{1}$, Rosa Andrie Asmara ${ }^{2}$, Atiqah Nurul Asri ${ }^{3}$ \\ ${ }^{1}$ Jurusan Teknik Elektro, ${ }^{2}$ Program Studi Teknik Informatika, ${ }^{3}$ Politeknik Negeri Malang \\ Email : galang.audi.p@gmail.com
}

\begin{abstract}
Abstrak
SPBU (Stasiun Pengisian Bahan Bakar Umum)Sera KM 25 Sidoarjo membutuhkan suatu sistem yang dapat melakukan pengolahan seluruh data yang berhubungan dengan proses penjualan dan pembelian BBM. Data-data yang saat ini diolah adalah data transaksi penjualan, data transaksi pembelian, data penggajian, data stok barang, data jabatan, data distributor, dan data user. Pengolahan data-data tersebut dalam sistem yang saat ini berjalan dilakukan secara manual yaitu diimplementasikan dalam buku atau arsip. Pengolahan data dengan menggunakan sistem yang saat ini berjalan dirasa kurang efisien dalam hal waktu dan kurang akurat dalam hal informasi yang dihasilkan. Masalah yang terdapat dalam sistem yang saat ini sedang berjalan dapat diselesaikan dengan membangun suatu sistem baru yang lebih efisien dan akurat.Pengembangan Aplikasi Keuangan pada SPBU Sera KM 25 Sidoarjo dibangun dengan menggunakan Visual Studio 2010 danSQL server 2008. Berdasarkan pengujian yang dilakukan, sistem yang dibangun dapat menyelesaikan masalah yang ada dalam sistem yang lama.
\end{abstract}

Katakunci: aplikasi keuangan, SPBU

\section{Pendahuluan}

Dalam pengembangan aplikasi keuangan sekarang ini sudah tidak lagi dilakukan secara manual, semua telah dilakukan secara komputerisasi. Dengan munculnya komputer dalam dunia kerja, hal ini dapat dimanfaatkan perusahaan dalam mengembangkan efektifitas pekerjaan berbasis teknologi sehingga pegawai mudah mengakses informasi kapanpun dan dimanapun.

Salah satu media implementasi berbasis teknologi komputer adalah Microsoft Visual Studio 2010 dan SQL Server 2008.Administrasi keuangan merupakan salah satu bagian dari aplikasi keuangan. Ruang lingkup dari administrasi keuangan meliputi aspek transaksi penjualan, pegawai, stok barang, laba-rugi, operasional dan pengadaan.

Identifikasi kebutuhan pengembangan berbantuan komputer dilakukan untuk mengetauhi kesulitan pegawai dalam proses perhitungan keuangan sebagai acuan dalam pengembangan aplikasi keuangan. Dalam perhitungan aplikasi keuangan ini dibahas dengan menggunakan Microsoft Visual Studio 2010 dan SQL Server 2008. Validasi dilakukan untuk memperoleh data dasar yang akan digunakan untuk menetapkan tingkat kevalidan media yang dikembangkan. Proses validasi dilakukan oleh subjek coba (validator) yang mempuni di bidang penelitian pengembangan dan bidang informatika sebagai ahli media.

\section{Metode}

\subsection{Perancangan}

\subsubsection{Analisa Permasalahan}

Pada tahap ini, dilakukan langkah-langkah untuk menganalisa permasalahan yang sedang terjadi. Dari hasil analisa tersebut, maka didapat laporan mengenai sumber permasalahan, akibat, dan juga solusi apa yang dibutuhkan.

\subsubsection{Analisa Kebutuhan}

Setelah apa yang menyebabkan permasalahan tersebut didapat, maka dibuatlah desain sistem yang bertujuan untuk memenuhi kebutuhan agar dapat menyelesaikan masalah tersebut. 
2.2 Pemodelan Sistem

2.2.1 Database Diagram

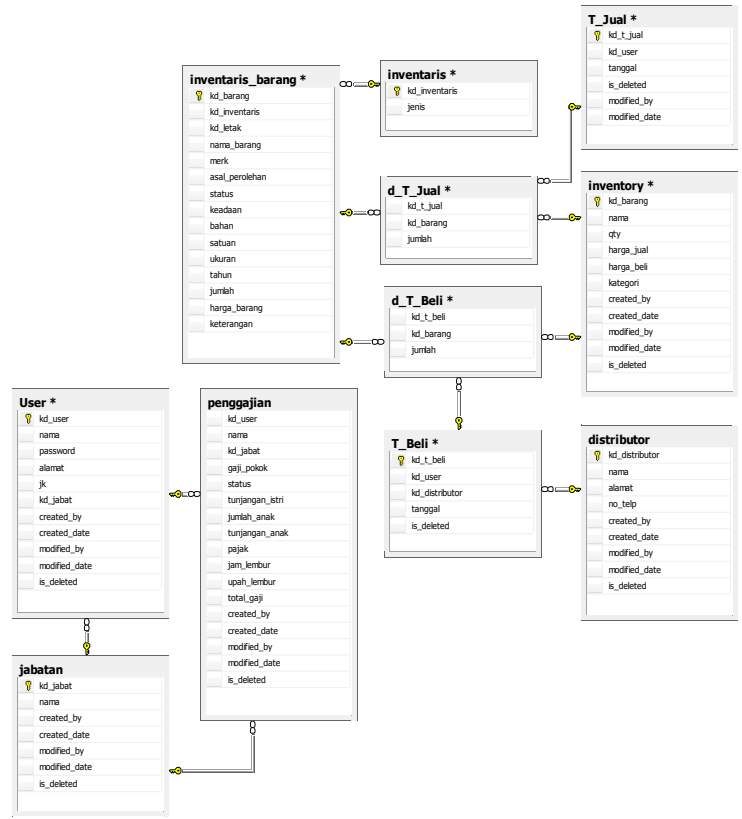

Gambar 2.1 Databse Diagram

\subsubsection{Work Breakdown Structure}

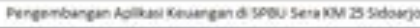

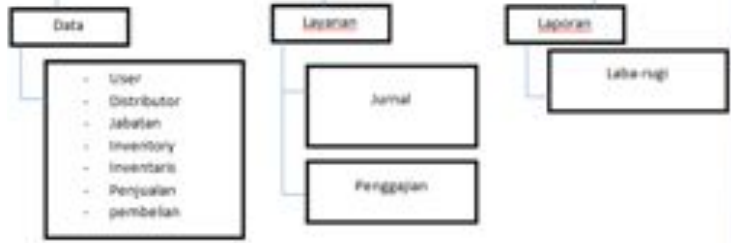

Gambar 2.2 Work Breakdown Structure

\subsubsection{Usecase}

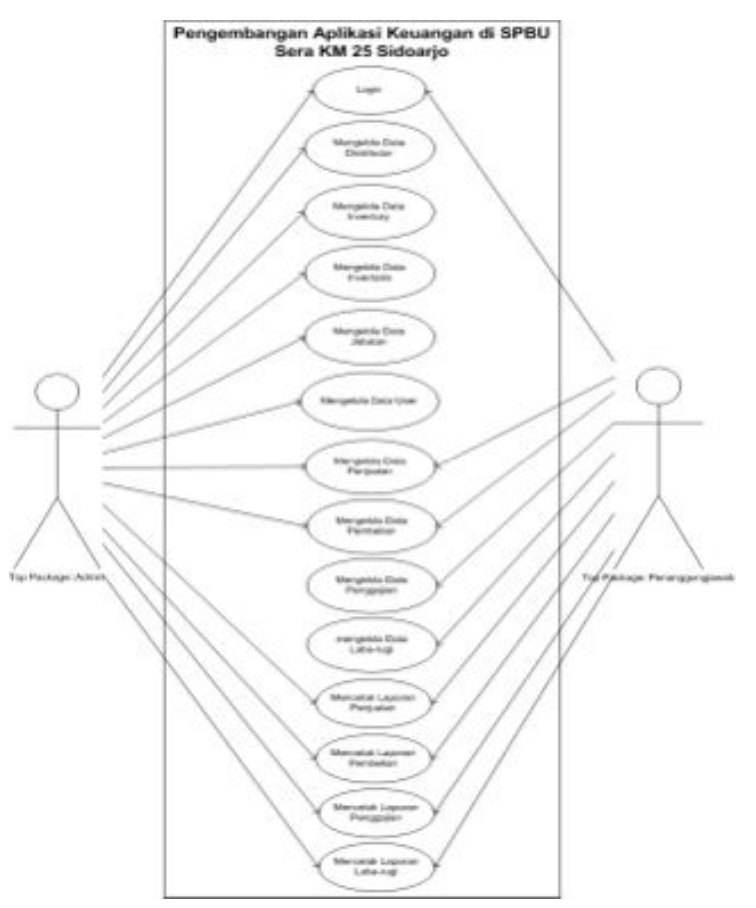

Gambar 2.3 Use Case Diagram

\subsubsection{Flowchart}

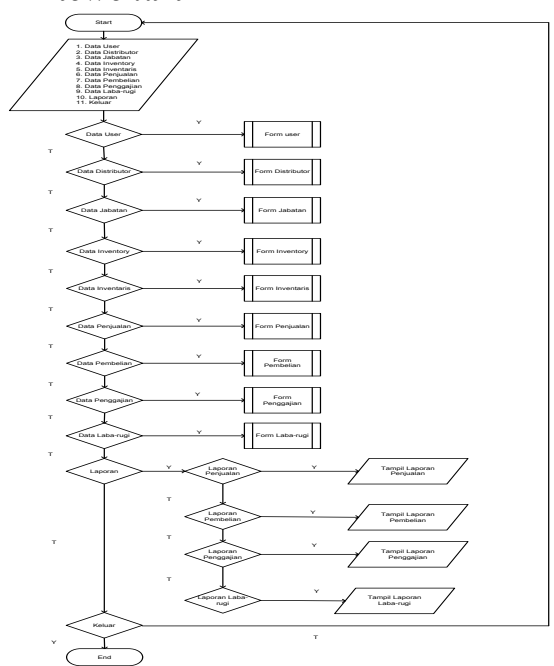

Gambar 2.4 Flowchart

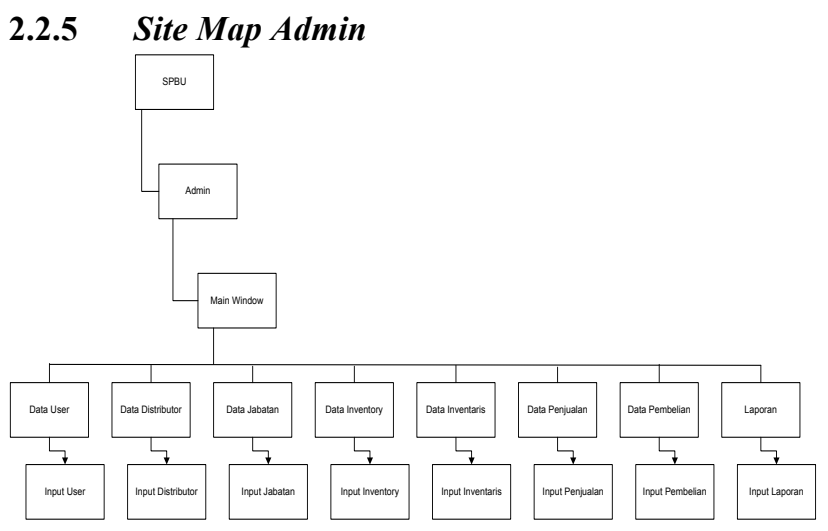

Gambar 2.5 Site Map Admin 


\subsubsection{Site Map Penanggungjawab}

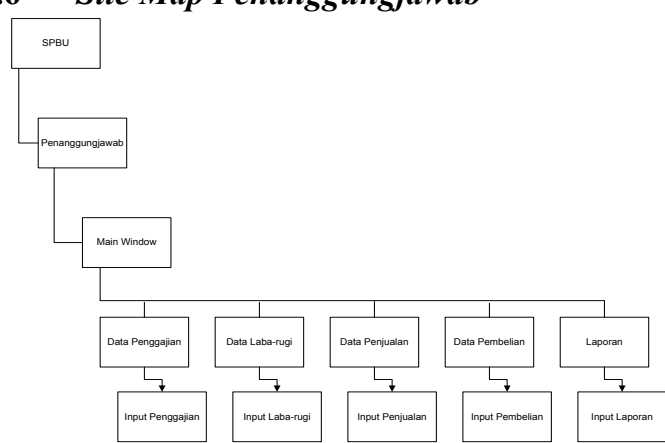

Gambar 2.6 Site Map Penanggungjawab

\section{Hasil}

Aplikasi yang dihasilkan memilikimain window, login, menu, penjualan, pembelian dan laba-rugi.

\subsection{Main Window}

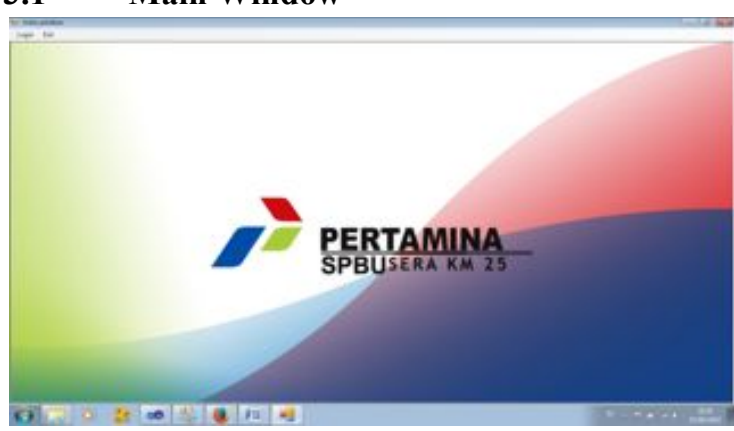

Gambar 3.1 Tampilan Main Window

\subsection{Login}

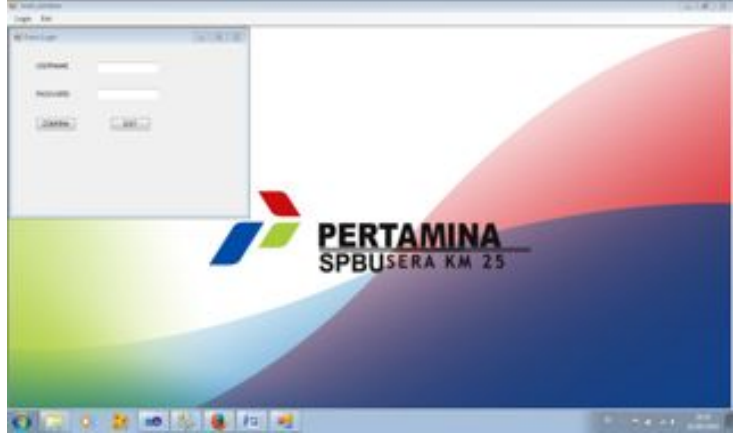

Gambar 3.2 Tampilan Login

\subsection{Menu}

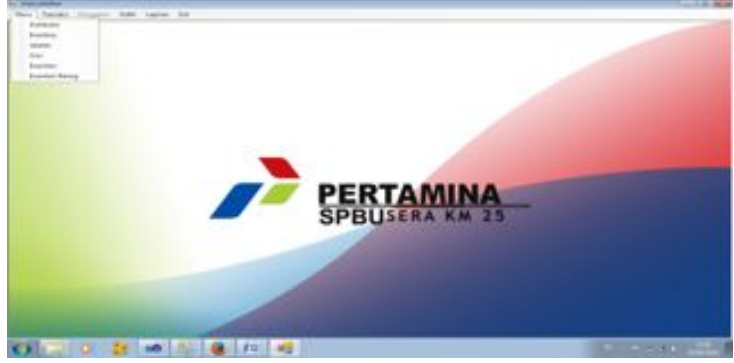

Gambar 3.3 Tampilan Menu

\subsection{Penjualan}

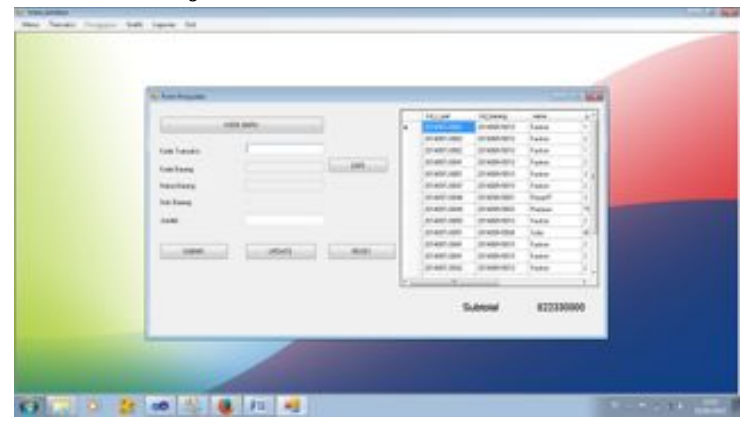

Gambar 3.4 Tampilan Penjualan

\subsection{Pembelian}

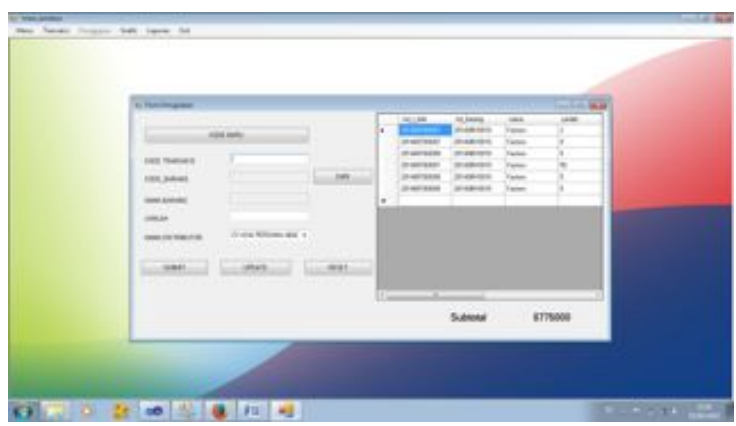

Gambar 3.5 Tampilan Pemelian

\subsection{Penggajian}

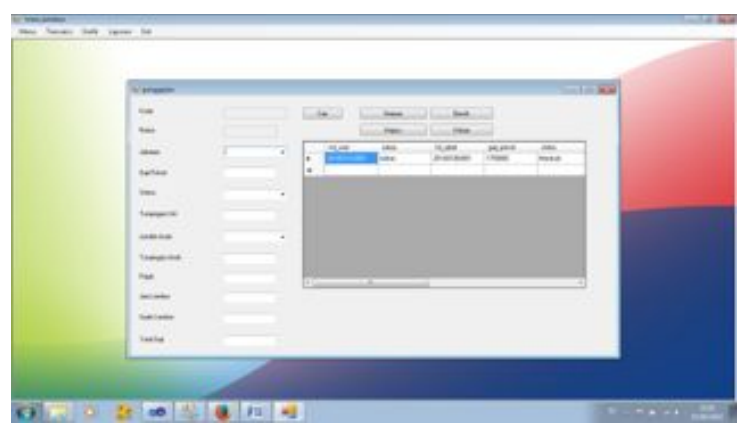

Gambar 3.6 Tampilan Penggajian

\subsection{Laba-rugi}




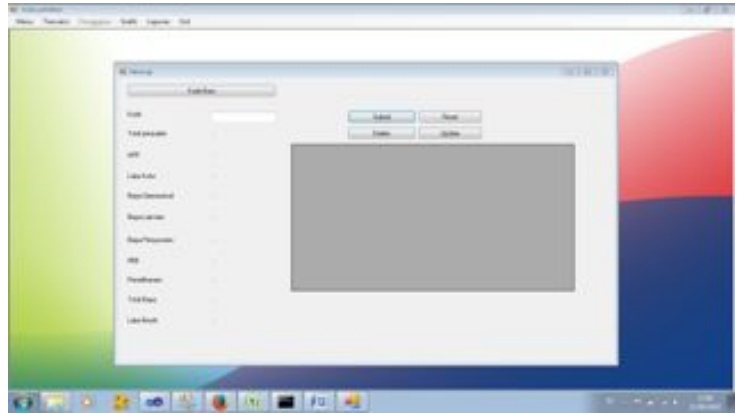

Gambar 3.7 Tampilan Laba-rugi

KM 25 Sidoarjo adalah Program aplikasi keuanga yang telah dibuat diharapkan dapat diterapkan dan dimanfaatkan dengan baik dan maksimal pada SPBU SERA KM 25 Sidoarjo sehingga nantinya bisa bermanfaat dalam pengelolaan transaksi keuangan dengan baik. Mengingat masih adanya kekurangan dalam program ini maka diharapkan program ini dapat didokumentasikan, sehingga dapat digunakan untuk pengembangan dan penyempurnaan program ini selanjutnya.

\section{Daftar Pustaka:}

\subsection{Kesimpulan}

Setelah menganalisa, mendesain dan mengimplementasikan Pengembangan Aplikasi Keuangan di SPBU SERA KM 25 Sidoarjo dapat disimpulkan bahwa dengan adanya pembuatan aplikasi keuangan yang mampu mempercepat proses transaksi keuangan sehingga tidak ada kendala lagi dalam masalah proses transaksi keuangan pada SPBU SERA KM 25 Sidoarjo, mampu meningkatkan efisiensi waktu dan efektifitas pekerjaan karena mempermudah proses penambahan, pengeditan, penjualan, pembelian dan penghapusan data serta transaksi-transaksi keuangan yang terjadi pada SPBU SERA KM 25 Sidoarjo. Penyajian informasi data transaksi penjualan lebih cepat dan akurat sehingga mengurangi tingkat kesalahan pada saat penginputan data transaksi penjualan dan pembelian yang disebabkan oleh Human Error. Mempercepat dan mempermudah dalam pencarian dan mencetak data SPBU, laporan transaksi penjualan, user, dan laba-rugi.

\subsection{Saran}

Saran yang berhubungan dengan program Pengembangan Aplikasi Keuangan di SPBU SERA

Kusrini. 2007. Strategi Perancangan dan Pengelolaan Basis Data. Yogyakarta: Andi.

Ni Nengah Armoni. 2007. Sistem Informasi. Yogyakarta: Ardana Media.

Hasanah.2011. Sistem Informasi Penjualan dan Pembelian Tunai Pada Toko Salam Menggunakan Micrisoft Visual Basic 6.0.Tugas Akhir. Univesitas Negeri Semarang.

Susanti, N. 2010. Buku Panduan Skripsi Sistem Informasi. Universitas Muria Kudus Fakultas Teknik Program Studi Sistem Informasi. Kudus.

Ikatan Akuntan Indonesia. 2007. Standar Akuntansi Keuangan. Jakarta: Salemba Empat.

Harahap, Sofyan Syafri. 2004. Analisis Kritis Atas Laporan Keuangan. Jakarta : PT. Raja Grafindo Persada.

Riyanto, Bambang. 2001, Dasar-dasar Pembelanjaan Perusahaan. Yogyakarta: BFE UGM.

Daryanto. 2003. Belajar Komputer Visual Basic. Bandung: Yrama Widya.

Divisi Penelitian dan Pengembangan MADCOMSMADIUN. 2005. Pemrograman Tingkat Lanjut dengan Visual Basic 6.0 dan Crystal Report. Yogyakarta: Andi. 